\title{
Optimum Control of Grazing and Cattle Movement in the Silvopastoral Establishment "La Aguada" (Córdoba-Argentina)
}

Sergio Drumond Ventura, Angel Ramon Sanchez Delgado, Vinicius Teixeira do Nascimento

Federal Rural University of Rio de Janeiro, Department of Mathematics, Brazil José Omar Plevich

Grupo de Dasonomía, Departamento Producción Vegetal, Facultad de Agronomía y Veterinaria - FAV, Universidad Nacional de Río Cuarto - UNRC, Río Cuarto/Córdoba,

Argentina

Received: May 26, 2019 Accepted: June 23, $2019 \quad$ Published: June 27, 2019

doi:10.5296/jas.v7i3.14832 URL: https://doi.org/10.5296/jas.v7i3.14832

\begin{abstract}
Currently silvopastoral systems have been presented as a viable and sustainable alternative in economic, social and environmental terms. The objective of this work is to present an integer linear programming model (ILP), that numerically represents or simulates the optimal operating conditions of a silvopastoral system inspired by the typology of the rural establishment "La Aguada", an experimental agricultural and forestry center, belonging to the National University of Rio Cuarto and located in the province of Córdoba (Argentina). The model imposes conditions on the adequacy of the gain of the live weight of each animal of the herd considered in the system, as well as the optimal control of the areas of pasture and bovine movement. It is important to highlight that this is an attempt to mathematically model improvements in food production systems. Each ILP was solved using the INTLINPROG solver in MATLAB software. Thus, after the computational implementation, it was verified that the program meets all restrictions imposed, maximizes the gain of the live weight of each animal and optimizes the pasture area use, thus showing a consistent, balanced and recommended program for the economic controlling of a silvopastoral system in general.
\end{abstract}

Keywords: animal confinement, soil compaction, pasture, animal transit

\section{Introduction}

Agroforestry systems are land use systems and technologies in which perennial woody species (trees, shrubs, palm trees, etc.) are used in the same system of management of 
agricultural crops and/or animal production, in some form of temporal or spatial arrangement. They combine production with the conservation of natural resources. In addition to seeking to meet the needs of the rural producers (food, wood, firewood, fodder, medicinal plants and fibers), they can assist in the conservation of soils, micro-basins, forest areas, biodiversity, among others (SILVA, 1998, MACEDO, et al., 2000, GARCIA, et al., 2004, SAIBRO, et al., 2004).

The silvopastoral systems (SPS) represent a modality of agroforestry systems (AFS), which cover production techniques that allow the integration of animals, pastures and trees in the same area. They represent a form of land use in which silvicultural and livestock activities are combined to generate production in a complementary way through the interaction of their components. In general, SPS s are systems in which forages and/or animals and trees are grown, simultaneously or sequentially, in the same area unit. The silvipastoral system is a technological option for integrating crop-livestock-forest (iCLF), which consists of the intentional combination of trees, pastures and livestock in the same area and at the same time (FRANKE \& FURTADO, 2001, BERNARDINO \& GARCIA, 2009).

The approval of Law 708/07 (04/02/2013), which establishes the National Policy for the integration of Livestock-Livestock-Forests (iCLF) in Brazil, reinforces the growing interest in the use of sustainable production systems. The iCLF is being proposed as a production strategy that includes, in its reference concepts, the main elements of sustainability, that is, economic, social and environmental. With the growing concern about the relationship between environment and livestock, the challenge arises to establish production systems on a sustainable basis and silvipastoral systems fit as a practice capable of meeting these elements.

The importance of SPS's can be easily understood for a number of reasons, namely: increasing the generated biodiversity; the protection of the soil against erosion and the improvement of its chemical and physical properties; the supply of better grazing during the dry season; the greater thermal comfort for the animal, provided by the shade of the trees and by the expressive control of the understory, carried out by grazing; increased cycling of nutrients in the system; the significant increase in the retention of carbon by the consortium, when compared to the exclusive forest or to the pasture in full sun. Regarding the livestock, the direct benefit is welfare and comfort. The presence of trees (suitably arranged in the pasture) can protect the animals against climatic adversities with a positive impact on the productivity and health of the animals.

Now, among criticisms of the SPS's are: the increase in competition among plant species; the difficulty of entering machinery in the area when the tree species does not have organized and planned distribution for mechanization; the damages promoted by the animals due to trampling; soil compaction and thinning or total loss of vegetation and permanence of components in the system that can serve as habitats or hosts for pests and diseases (SANTOS, 2010). In this work, hoping to contribute to animal performance and combat possible animal damages in an SPS, we try to model the optimum control of pasture and bovine movement using integer linear programming (ILP). In the literature, GALDINO DE OLIVEIRA, et al., 2019, presented numerical simulations of crop rotation and animal transit in integrated 


\section{Macrothink}

crop-livestock systems using ILP. The result was the generation of optimal schedules in relation to crop rotation and animal traffic. The SPS considered here represents a topological abstraction of the SPS located in the rural establishment "La Aguada". This is a center for experimental agricultural and forestry, belonging to the National University of Rio Cuarto and located in the province of Córdoba (Argentina).

\section{Material and Methods}

The objective of this study was the development of an integer linear programming model (NEMHAUSER \& WOLSEY, 1999) for optimal control of pasture and cattle movement in the silvopastoral system, which we will consider here. The whole programming problem is a type of linear programming problem in which the variables must assume the values 0 or 1 , also known as binary program. This type of program is widely used in the search for solutions, where the value 1 means that the characteristic is present and value 0 means it is absent. As in other areas, whole programming can be used efficiently in the operational management of production of a silvopastoral system, when it is sought to achieve the efficient use of available resources. It is important to emphasize that because it is a combinatorial model, there is a limitation regarding the size of the problem (number of variables and constraints).

The silvopastoral system to be considered, named SPS-La Aguada, was represented in Figure 1. As said before, it is (in a certain way) a typology of the SPS developed in the establishment "La Aguada" (Córdoba-Argentina) and presented in PLEVICH, et. al., 2019. The SPS-LA represents a structure composed of five areas or units of pasture and cattle-raising activities: the areas of pasture without trees, north and south, areas of animal confinement (composition of food, feed and/or pasture, matter dry, crude protein, etc.), north and south respectively, and a silvopastoral area (pasture + trees). The arrows indicate the possible allowed animal transit of the herd in the system. The areas of animal confinement (north and south) are where a certain number of animals can be fed with various diets that make them express all their genetic characteristics, especially the gain of live weight. 


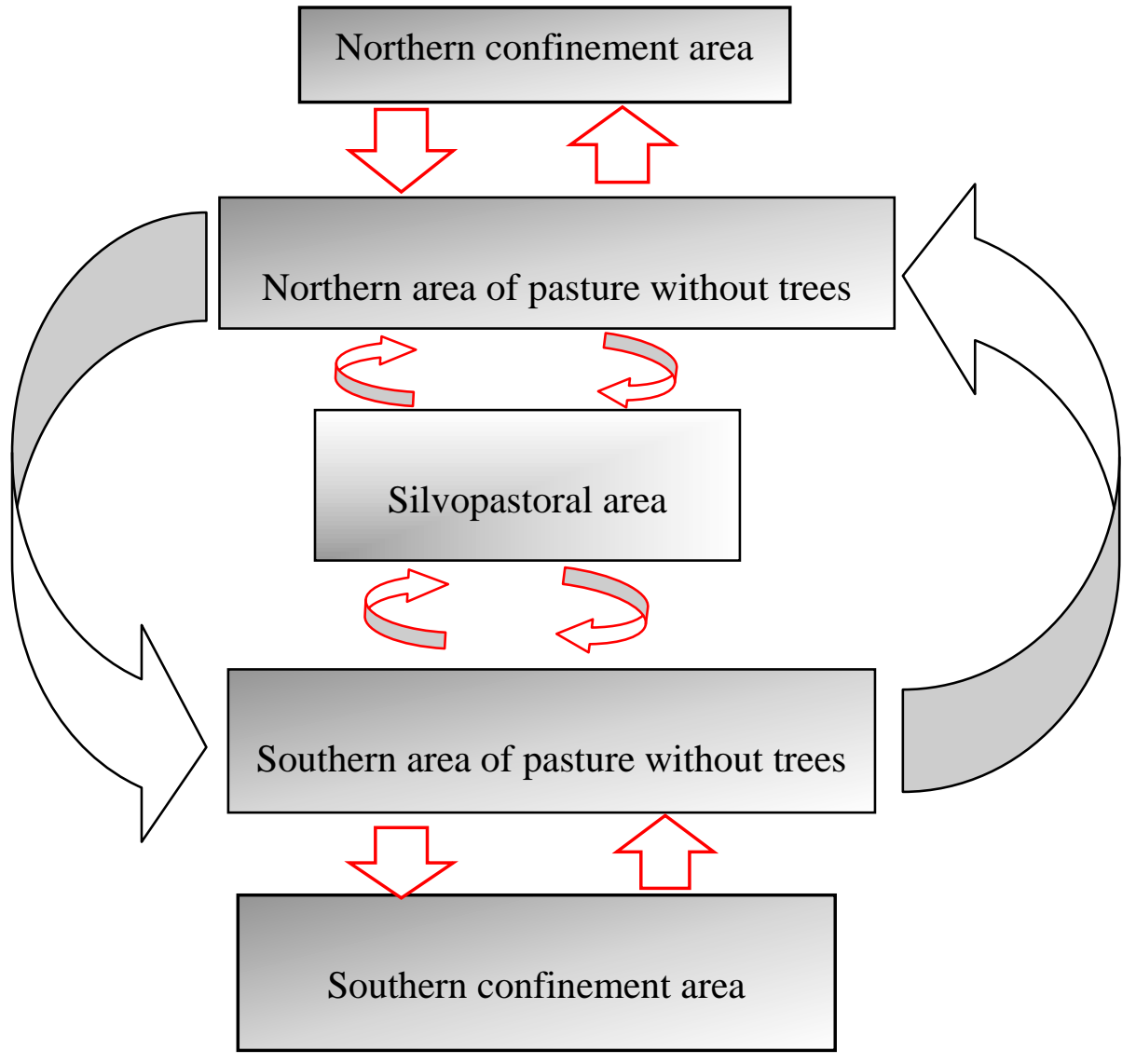

Figure 1. Silvopastoral-La Aguada System (SPS-LA)

Source: Authors

Considering that confinement is costly, when compared to the other areas, this area should be used as a tool for livestock and not as a total production system, that is, the animal is taken to this area only when it is indispensable and for the shortest period possible. In the final stage of fattening for the slaughter of the animal, only animals that present live weight much under the weight for its age can remain confined. Otherwise, the animals should be moved to the grassless areas or the silvopastoral area.

Grassland areas without trees (north and south) are central areas of animal traffic. The pastures considered may be natural, native or artificial. The choice varies, taking into account the creation, soil and climate of the region, in addition to the property conditions.

In the natural pastures we have the original vegetation composed by various species of herbaceous, grasses, non-grasses and shrub. In the native pastures we have spontaneous vegetation composed by the type of fodder value that grows after the destruction of the original vegetation. Finally, the artificial pastures may be composed of exotic or native species, where there is no more original vegetation, and may be of the permanent type (lasting up to 30 years) and temporary (lasting up to 6 months), being cultivated the varieties of grasses of the genera: brachiarias, panicummaximum, andropogon and cynodon. 


\section{Macrothink}

For the so-called silvopastoral area, there is the combination of pasture and trees (pine, cedar or eucalyptus). In this way we offer well-being and thermal comfort to the animal. The presence of trees (suitably arranged in the pasture) can protect the animals against climatic adversities. Regarding animal traffic, key to the success of the SPS-LA, certain rules allowing a harmony between the pasture and the live weight of each animal must be respected. Among them are the maximum number of animals allowed in each area of the SPS-LA, which aims to reduce soil compaction by animal trampling. Recall that compression is a dynamic and progressive process that leads to a densification proportional to the volume of loads exerted on it. Poorly managed grazing can cause both soil porosity and soil water infiltration and storage capacity to be reduced. In inadequately conducted systems, allowing the animals to remain for a longer period than recommended, will result in compaction of the topsoil.

Note in Figure 1 that the animals in the pasture area can rotate with the silvopastoral area whenever necessary. Also depending on the live weight of each animal, we allow animal movement between pasture areas without north-south trees, respectively. In general, the criterion used to pass an animal from one area to another will depend on the live weight of the animal and the fitness of each area of the SPS-LA. In this way it is possible to imagine that we have a set of routes or viable paths between the confinement areas (north and south), pasture without trees (north and south) and silvipastoral area, among which we wish to choose the optimal route of circulation that each herd animal will have to perform during the deployment of the system.

In what follows, the construction of an ILP model to represent some rules about animal circulation in the SPS-LA, in order to have an optimal control of the animal traffic (seeking to maximize the live weight of each animal) and the pasture area without trees and the silvopastoral area. Then the indexes, parameters, variables, constraints and objective of the whole linear programming model associated to the activities of the SPS-LA.

\section{Indexes}

$i=1, \ldots, n$; where $n$ represents the number of animals of the herd considered,

$j=1-$ northern area of pasture without trees, $j=2-$ southern area of pasture without trees,

$j=3-$ silvopastoral area, $j=4-$ northern confinement area and $j=5-$ southern confinement area.

$k=1, \ldots, 12 \quad$ (months of the year).

\section{Parameters}

$P V_{i j}-$ Live weight of animal $i$, in the area $j(\mathrm{~kg})$. 
$P V A_{i j}-$ Live weight for abatement of animal $i$, in the area $j(\mathrm{~kg})$.

$g_{i j k}-$ Weight gained by animal $i$ in the area $j$ in the month $k .(k g)$.

$c_{i j k}-$ Cost for the area $j$ to be able to receive animal $i$ during the month $k$.

For each area $j$, let $S_{j}=\left\{i: P V_{i j}<P V A_{i j}\right\}$ and $\overline{S_{j}}=\left\{i: P V_{i j} \ll P V A_{i j}\right\}$. Both sets indicate the animals with insufficient live weight for the slaughter and extremely low for the slaughter respectively.

\section{Variables}

$$
\begin{aligned}
& x_{i j k}= \begin{cases}1, & \text { If the area } j \text { is able to receive animal } i \text { in the month } k, \\
0, & \text { Otherwise. }\end{cases} \\
& y_{i j k}= \begin{cases}1, & \text { If animal } i \text { is in the area } j \text { in the month } k_{u} \\
0, & \text { Otherwise. }\end{cases}
\end{aligned}
$$

\section{Constraints}

i) For each month $k$, the number of $i$ animals that may stay in the area $j$, cannot exceed $N_{j k}$ animals.

$$
\sum_{i=1}^{n} y_{i j k} \leq N_{i k}, \quad j=1,2,3,4,5, \quad k=1, \ldots, 12 .
$$

ii) Each animal $i$ must be in one and only one area $j$ for each month $k$.

$$
\sum_{j=1}^{5} y_{i j k}=1, \quad i=1, \ldots, n, \quad k=1, \ldots, 12
$$

iii) If animal $i$ is in the northern area of pasture without trees $(j=1)$ in month $k$, with live weight strictly smaller than the appropriate weight for its abatement, and in month $k+1$, the silvipastoral area $(j=3)$ is able to receive this animal, then the animal can be moved to the silvopastoral area in month $k+1$. 


$$
x_{i 1 k} \leq y_{i 3(k+1)}, \quad i \in S_{1}=\left\{i: P V_{i 1}<P V A_{i 1}\right\}, \quad k=1, \ldots, 11 .
$$

iv) If animal $i$ is in the southern area of pasture without trees $(j=2)$ in month $k$, with live weight strictly smaller than the appropriate weight for its abatement, and in month $k+1$, the silvopastoral area $(j=3)$ is able to receive this animal, then the animal can be moved to the silvopastoral area in month $k+1$.

$$
x_{i 2 k} \leq y_{i 3(k+1)}, \quad i \in S_{2}=\left\{i: P V_{i 2}<P V A_{i 2}\right\}, \quad k=1, \ldots, 11 .
$$

v) If animal $i$ is in the silvopastoral area $(j=3)$ in month $k$, with live weight strictly smaller than the appropriate weight for its abatement, and in month $k+1$, the northern area of pasture without trees $(j=1)$ is able to receive this animal, then the animal can be moved to the northern area of pasture without trees in month $k+1$.

$$
x_{i 3 k} \leq y_{i 1(k+1)}, \quad i \in S_{3}=\left\{i: P V_{i 3}<P V A_{i 3}\right\}, \quad k=1, \ldots, 11 .
$$

vi) If animal $i$ is in the silvopastoral area $(j=3)$ in month $k$, with live weight strictly smaller than the appropriate weight for its abatement, and in month $k+1$, the southern area of no-tree pasture $(j=2)$ is able to receive this animal, then the animal can be moved to the southern area of pasture without trees in month $k+1$.

$$
x_{i 3 k} \leq y_{i 2(k+1)}, \quad i \in S_{3}=\left\{i: P V_{i 3}<P V A_{i 3}\right\}, \quad k=1, \ldots, 11 .
$$

vii) If animal $i$ is in the northern area of pasture without trees $(j=1)$ in month $k$, with live weight extremely lower than the appropriate weight for its abatement, then the animal 
can be moved to the northern area of confinement in month $k+1$.

$$
y_{i 1 k} \leq y_{i 4(k+1)}, \quad i \in \overline{S_{1}}=\left\{i: P V_{i 1} \ll P V A_{i 1}\right\}, \quad k=1, \ldots, 11 .
$$

viii) If animal $i$ is in the southern area of pasture without trees $(j=2)$ in month $k$, with live weight extremely lower than the appropriate weight for its abatement, then the animal can be moved to the southern area of confinement in month $k+1$.

$$
y_{i 2 k} \leq y_{i 5(k+1)}, \quad i \in \overline{S_{2}}=\left\{i: P V_{i 2} \ll P V A_{i 2}\right\}, \quad k=1, \ldots, 11 .
$$

ix) If animal $i$ is in the north area of pasture without trees $(j=1)$ in month $k$, with live weight strictly smaller than the appropriate weight for its abatement, and in month $k+1$, the southern area of pasture without trees $(j=2)$ is able to receive this animal, then the animal can be moved to the southern area of pasture without trees in month $k+1$.

$$
x_{i 1 k} \leq y_{i 2(k+1),} \quad i \in S_{1}=\left\{i: P V_{i 1}<P V A_{i 1}\right\}, \quad k=1, \ldots, 11
$$

$\mathrm{x}$ ) If animal $i$ is in the southern area of pasture without trees $(j=2)$ in month $k$, with live weight strictly smaller than the appropriate weight for its abatement, and in month $k+1$, the northern area of pasture without trees $(j=1)$ is able to receive this animal, then the animal can be moved to the northern area of pasture without trees in month $k+1$.

$$
x_{i 2 k} \leq y_{i 1(k+1),} \quad i \in S_{2}=\left\{i: P V_{i 2}<P V A_{i 2}\right\}, \quad k=1, \ldots, 11
$$

xi) If animal $i$ is in the northern area of confinement $(j=4)$ in month $k$, with live weight strictly smaller than the appropriate weight for its abatement, then the animal must remain in that area in month $k+1$.

$$
y_{i 4 k} \leq y_{i 4(k+1),} \quad i \in S_{4}=\left\{i: P V_{i 4}<P V A_{i 4}\right\}, \quad k=1, \ldots, 11
$$


xii) If animal $i$ is in the southern area of confinement $(j=5)$ in month $k$, with live weight strictly smaller than the appropriate weight for its abatement, then the animal must remain in that area in month $k+1$.

$$
y_{i 5 k} \leq y_{i 5(k+1)}, \quad i \in S_{5}=\left\{i: P V_{i 5}<P V A_{i 5}\right\}, \quad k=1, \ldots, 11 .
$$

xiii) If animal $i$ is in the northern area of confinement $(j=4)$ in month $k$, with live weight extremely lower than the appropriate weight for its abatement, then that animal must remain in the same area in the following two months.

$$
\begin{array}{lll}
y_{i 4 k} \leq y_{i 4(k+1),} & i \in \overline{S_{4}}=\left\{i: P V_{i 4} \ll P V A_{i 4}\right\}, & k=1, \ldots, 11, \\
y_{i 4 k} \leq y_{i 4(k+2),}, & i \in \overline{S_{4}}=\left\{i: P V_{i 4} \ll P V A_{i 4}\right\}, & k=1, \ldots, 10 .
\end{array}
$$

xiv) If animal $i$ is in the southern area of confinement $(j=5)$ in month $k$, with live weight extremely lower than the appropriate weight for its abatement, then that animal must remain in the same area in the following two months.

$$
\begin{array}{lll}
y_{i 5 k} \leq y_{i 5(k+1),} & i \in \overline{S_{4}}=\left\{i: P V_{i 5} \ll P V A_{i 5}\right\}, & k=1, \ldots, 11, \\
y_{i 5 k} \leq y_{i 5(k+2),} & i \in \overline{S_{4}}=\left\{i: P V_{i 5} \ll P V A_{i 5}\right\}, & k=1, \ldots, 10 .
\end{array}
$$

$\mathrm{xv)} \mathrm{Each} \mathrm{animal} \mathrm{must} \mathrm{have} \mathrm{at} \mathrm{least} \mathrm{one} \mathrm{area} \mathrm{in} \mathrm{the} \mathrm{SPS-LA} \mathrm{every} \mathrm{month} \mathrm{of} \mathrm{the} \mathrm{year.}$

$$
\sum_{j=1}^{5} x_{i j k} \geq 1, \quad i=1, \ldots, n, \quad k=1, \ldots, 12
$$

xvi) If animal $i$ is in the northern area of confinement $(j=4)$ in month $k$, with live weight strictly smaller than the appropriate weight for its abatement, then the animal should not be in the silvipastoral area $(j=3)$ in month $k+1$.

$$
y_{i 4 k}+y_{i 3(k+1)} \leq 1, \quad k=1, \ldots, 11
$$

xvii) If animal $i$ is in the silvipastoral area $(j=3)$ in month $k$, with live weight strictly smaller than the appropriate weight for its abatement, then the animal should not be in the 
northern area of confinement $(j=4)$ in month $k+1$.

$$
y_{i 3 k}+y_{i 4(k+1)} \leq 1, \quad k=1, \ldots, 11
$$

xviii) If animal $i$ is in the northern area of confinement $(j=4)$ in month $k$, with live weight strictly smaller than the appropriate weight for its abatement, then the animal should not be in the southern area of pasture without trees $(j=2)$ in month $k+1$.

$$
y_{i 4 k}+y_{i 2(k+1)} \leq 1, \quad k=1, \ldots, 11 \text {. }
$$

xix) If animal $i$ is in the southern area of unmanaged pasture $(j=2)$ in month $k$, with live weight strictly less than the appropriate weight for its abatement, then the animal should not be in the northern area of confinement $(j=4)$ in month $k+1$.

$$
y_{i 2 k}+y_{i 4(k+1)} \leq 1, \quad k=1, \ldots, 11 \text {. }
$$

$\mathrm{xx}$ ) If animal $i$ is in the northern area of confinement $(j=4)$ in month $k$, with live weight strictly smaller than the appropriate weight for its abatement, then the animal should not be in the southern confinement area $(j=5)$ in month $k+1$.

$$
y_{i 4 k}+y_{i 5(k+1)} \leq 1, \quad k=1, \ldots, 11
$$

xxi) If animal $i$ is in the southern confinement area $(j=5)$ in month $k$, with live weight strictly smaller than the appropriate slaughter weight, then the animal should not be in the northern confinement area $(j=4)$ at month $k+1$.

$$
y_{i 5 k}+y_{i 4(k+1)} \leq 1, \quad k=1, \ldots, 11
$$

xxii) If the animal $i$ is in the northern area of pasture without trees $(j=1)$ in month $k$, with a live weight strictly smaller than the appropriate weight for its abatement, then the animal should not be in the southern confinement area $(j=5)$ in month $k+1$. 


$$
y_{i 1 k}+y_{i 5(k+1)} \leq 1, \quad k=1, \ldots, 11
$$

xxiii) If animal $i$ is in the southern area of confinement $(j=5)$ in month $k$, with live weight strictly smaller than the appropriate weight for its abatement, then the animal should not be in the northern area of pasture without trees $(j=1)$ in month $k+1$.

$$
y_{i 5 k}+y_{i 1(k+1)} \leq 1, \quad k=1, \ldots, 11 .
$$

xxiv) If animal $i$ is in the area of silvipastoral $(j=3)$ in month $k$, with live weight strictly smaller than the appropriate weight for its abatement, then the animal should not be in the southern confinement area $(j=5)$ in month $k+1$.

$$
y_{i 3 k}+y_{i 5(k+1)} \leq 1, \quad k=1, \ldots, 11
$$

$\mathrm{xxv}$ ) If animal $i$ is in the southern area of confinement $(j=5)$ in month $k$, with live weight strictly smaller than the appropriate weight for its abatement, then the animal should not be in the Silvipastoral area $(j=3)$ in month $k+1$.

$$
y_{i 5 k}+y_{i 3(k+1)} \leq 1, \quad k=1, \ldots, 11 .
$$

xxvi) Animal $i$ can only occupy area $j$ in month $k$, if this area is available to be occupied.

$$
y_{i j k} \leq x_{i j k}, \quad j=1,2,3,4,5, \quad k=1, \ldots, 12, \quad i=1, \ldots, n
$$

The ILP for optimal control of pasture and cattle movement in the SPS-LA can be represented as follows, considering that the computational language used to determine optimal solutions was a MATLAB variant:

Maximize $\sum_{i=1}^{n} \sum_{j=1}^{5} \sum_{k=1}^{12} g_{i j k} y_{i j k}-\sum_{i=1}^{n} \sum_{j=1}^{5} \sum_{k=1}^{12} c_{i j k} x_{i j k}$ 
Subject to:

$$
\begin{aligned}
& \sum_{i=1}^{n} y_{i j k} \leq N_{i k}, \quad j=1,2,3,4,5, \quad k=1, \ldots, 12 \\
& \sum_{j=1}^{5} y_{i j k}=1, \quad i=1, \ldots, n, \quad k=1, \ldots, 12 \\
& x_{i 1 k} \leq y_{i 3(k+1),} \quad i \in S_{1}=\left\{i: P V_{i 1}<P V A_{i 1}\right\}, \quad k=1, \ldots, 11 \\
& x_{i 2 k} \leq y_{i 3(k+1),} \quad i \in S_{2}=\left\{i: P V_{i 2}<P V A_{i 2}\right\}, \quad k=1, \ldots, 11 ; \\
& x_{i 3 k} \leq y_{i 1(k+1),} \quad i \in S_{3}=\left\{i: P V_{i 3}<P V A_{i 3}\right\}, \quad k=1, \ldots, 11 \\
& x_{i 3 k} \leq y_{i 2(k+1),} \quad i \in S_{3}=\left\{i: P V_{i 3}<P V A_{i 3}\right\}, \quad k=1, \ldots, 11 ; \\
& y_{i 1 k} \leq y_{i 4(k+1)}, \quad i \in \overline{S_{1}}=\left\{i: P V_{i 1} \ll P V A_{i 1}\right\}, \quad k=1, \ldots, 11 ; \\
& y_{i 2 k} \leq y_{i 5(k+1),} \quad i \in \overline{S_{2}}=\left\{i: P V_{i 2} \ll P V A_{i 2}\right\}, \quad k=1, \ldots, 11 ; \\
& x_{i 2(k+1)} \leq y_{i 2(k+1)}, \quad i \in S_{1}=\left\{i: P V_{i 1}<P V A_{i 1}\right\}, \quad k=1, \ldots, 11 ; \\
& x_{i 1(k+1)} \leq y_{i 1(k+1)}, \quad i \in S_{2}=\left\{i: P V_{i 2}<P V A_{i 2}\right\}, \quad k=1, \ldots, 11 \\
& y_{i 4 k} \leq y_{i 4(k+1),} \quad i \in S_{4}=\left\{i: P V_{i 4}<P V A_{i 4}\right\}, \quad k=1, \ldots, 11 \\
& y_{i 5 k} \leq y_{i 5(k+1)}, \quad i \in S_{5}=\left\{i: P V_{i 5}<P V A_{i 5}\right\}, \quad k=1, \ldots, 11 \\
& y_{i 4 k} \leq y_{i 4(k+1)}, \quad i \in \overline{S_{4}}=\left\{i: P V_{i 4} \ll P V A_{i 4}\right\}, \quad k=1, \ldots, 11 \\
& y_{i 4 k} \leq y_{i 4(k+2),} \quad i \in \overline{S_{4}}=\left\{i: P V_{i 4} \ll P V A_{i 4}\right\}, \quad k=1, \ldots, 10 \\
& y_{i 5 k} \leq y_{i 5(k+1)}, \quad i \in \overline{S_{5}}=\left\{i: P V_{i 5} \ll P V A_{i 5}\right\}, \quad k=1, \ldots, 11 \\
& y_{i 5 k} \leq y_{i 5(k+2),} \quad i \in \overline{S_{5}}=\left\{i: P V_{i 5} \ll P V A_{i 5}\right\}, \quad k=1, \ldots, 10
\end{aligned}
$$




$$
\sum_{k=1}^{12} x_{i j k} \geq 1, \quad i=1, \ldots, n, \quad j=1,2,3,4,5
$$$$
y_{i 4 k}+y_{i 3(k+1)} \leq 1, \quad k=1, \ldots, 11
$$$$
y_{i 3 k}+y_{i 4(k+1)} \leq 1, \quad k=1, \ldots, 11
$$$$
y_{i 4 k}+y_{i 2(k+1)} \leq 1, \quad k=1, \ldots, 11
$$$$
y_{i 2 k}+y_{i 4(k+1)} \leq 1, \quad k=1, \ldots, 11
$$$$
y_{i 4 k}+y_{i 5(k+1)} \leq 1, \quad k=1, \ldots, 11
$$$$
y_{i 5 k}+y_{i 4(k+1)} \leq 1, \quad k=1, \ldots, 11
$$$$
y_{i 1 k}+y_{i 5(k+1)} \leq 1, \quad k=1, \ldots, 11
$$$$
y_{i 5 k}+y_{i 1(k+1)} \leq 1, \quad k=1, \ldots, 11
$$$$
y_{i 3 k}+y_{i 5(k+1)} \leq 1, \quad k=1, \ldots, 11
$$$$
y_{i 5 k}+y_{i 3(k+1)} \leq 1, \quad k=1, \ldots, 11
$$$$
y_{i j k} \leq x_{i j k}, \quad j=1,2,3,4,5, k=1, \ldots, 12, \quad i=1, \ldots, n ;
$$$$
x_{i j k}, y_{i j k} \in\{0,1\} \text {. }
$$

In Linear Programming (LP), there are theoretically proven necessary and sufficient conditions of optimization that can be used to efficiently test whether a given feasible solution is an optimal solution or not. These conditions have been used to develop algebraic methods such as simplex and other methods to solve LP problems. In integer linear programming, there are no known optimization conditions to test whether a given viable solution is optimal except by explicitly or implicitly comparing this solution with each of the feasible solutions to the problem. This is the reason why these are solved by means of enumeration methods that look for optimal solution in the set of viable solutions, as in our case. With the computational implementation we could verify that the program satisfies all imposed constraints, maximizes the weight gain of each animal and minimizes the costs. 


\section{Macrothink

The computational implementation of the ILP model associated with the activities of the SPS-LA was performed on the MATLAB platform. The data on the weight gain for each animal in the herd considered, the cost for a given area to be able to receive a particular animal in each month of the year and the number of animals that can remain in a certain area of the SPS-LA in each month of the year, were randomly generated.

\section{Results and Discussion}

We started by pointing out that the silvipastoral platform (SPS-LA) under which we mathematically formulated the set of rules associated with the control of pasture and animal traffic considered here, represents the operational structure of a silvopastoral system in the abstract typology of the agroforestry center "La Aguada ", at the National University of Rio Cuarto (Córdoba-Argentina). It is composed of five physical areas for the development of agricultural and livestock activities, and where animal concentrations can be carried out, whenever there are adequate conditions of the corresponding area to feed a given number of animals of the herd during a certain month of the year. In this case, we say that the area can receive the corresponding animal, or that the animal can occupy the corresponding area, or that the area is able to be occupied. To validate the proposed model, two scenarios were considered: the first one with a herd of three animals and the second one with five animals. For both scenarios, the parameters of the entire linear programming model were randomly generated.

In the first scenario, Table 1 shows the results obtained for animals that may have had adequate feeding to gain fat in a certain area of SPS-LA $\left(x_{i j k}\right)$. Note that the northern and southern confinement areas are the only areas with adequate conditions to feed at least one herd animal during any month of the year: the northern confinement area can feed any of the three animals in months 8 and 12, while the southern confinement area can only feed any animal in month 3 . Note also that animal 2 can only receive feed in northern and southern areas for any month of the year. In the northern area of no-tree pasture, it is not possible to feed any animal in months 6,8,9 and 12, while at month 6, animal 1 may have the southern confinement area or the southern pasture area without trees for their feeding, animal 2 from the northern or southern confinement area, and animal 3 from the southern area of no-tree pasture or from the northern confinement area. 
Table 1. Availability of areas suitable for three (3) animals

\begin{tabular}{|c|c|c|c|c|c|}
\hline & $\begin{array}{c}\text { Northern } \\
\text { confinement } \\
\text { area }\end{array}$ & $\begin{array}{c}\text { Northern } \\
\text { area of pasture } \\
\text { without tree }\end{array}$ & $\begin{array}{c}\text { Silviopastoral } \\
\text { area }\end{array}$ & $\begin{array}{l}\text { Southern } \\
\text { area of pasture } \\
\text { without tree }\end{array}$ & $\begin{array}{c}\text { Southern } \\
\text { confinement } \\
\text { area }\end{array}$ \\
\hline $\begin{array}{c}\text { Month } \\
1\end{array}$ & $\begin{array}{l}\text { Animal } 2 \\
\text { Animal } 3\end{array}$ & Animal 1 & & Animal 1 & $\begin{array}{l}\text { Animal } 2 \\
\text { Animal } 3\end{array}$ \\
\hline${ }_{2}^{\text {Month }}$ & $\begin{array}{l}\text { Animal } 2 \\
\text { Animal } 3\end{array}$ & Animal 1 & & Animal 1 & $\begin{array}{l}\text { Animal } 2 \\
\text { Animal } 3\end{array}$ \\
\hline $\begin{array}{c}\text { Month } \\
3\end{array}$ & Animal 2 & $\begin{array}{l}\text { Animal } 1 \\
\text { Animal } 3\end{array}$ & & & $\begin{array}{l}\text { Animal } 1 \\
\text { Animal } 2 \\
\text { Animal } 3\end{array}$ \\
\hline $\begin{array}{c}\text { Month } \\
4\end{array}$ & $\begin{array}{l}\text { Animal } 1 \\
\text { Animal } 2\end{array}$ & $\begin{array}{l}\text { Animal } 1 \\
\text { Animal } 3\end{array}$ & & Animal 3 & Animal 2 \\
\hline $\begin{array}{l}\text { Month } \\
5\end{array}$ & Animal 2 & $\begin{array}{l}\text { Animal } 1 \\
\text { Animal } 3\end{array}$ & Animal 1 & Animal 3 & Animal 2 \\
\hline $\begin{array}{c}\text { Month } \\
6\end{array}$ & $\begin{array}{l}\text { Animal } 2 \\
\text { Animal } 3\end{array}$ & & & $\begin{array}{l}\text { Animal } 1 \\
\text { Animal } 3\end{array}$ & $\begin{array}{l}\text { Animal } 1 \\
\text { Animal } 2\end{array}$ \\
\hline $\begin{array}{c}\text { Month } \\
7 \\
\end{array}$ & $\begin{array}{l}\text { Animal } 2 \\
\text { Animal } 3\end{array}$ & Animal 1 & & $\begin{array}{l}\text { Animal } 1 \\
\text { Animal } 3\end{array}$ & Animal 2 \\
\hline $\begin{array}{c}\text { Month } \\
8\end{array}$ & $\begin{array}{l}\text { Animal 1 } \\
\text { Animal } 2 \\
\text { Animal } 3\end{array}$ & & Animal 1 & Animal 3 & Animal 2 \\
\hline $\begin{array}{l}\text { Month } \\
9\end{array}$ & $\begin{array}{l}\text { Animal } 2 \\
\text { Animal } 3\end{array}$ & & Animal 1 & $\begin{array}{l}\text { Animal } 1 \\
\text { Animal } 3\end{array}$ & Animal 2 \\
\hline $\begin{array}{l}\text { Month } \\
10\end{array}$ & Animal 2 & Animal 3 & Animal 1 & $\begin{array}{l}\text { Animal } 1 \\
\text { Animal } 3\end{array}$ & Animal 2 \\
\hline $\begin{array}{c}\text { Month } \\
11\end{array}$ & $\begin{array}{l}\text { Animal } 2 \\
\text { Animal } 3\end{array}$ & Animal 1 & Animal 1 & Animal 3 & Animal 2 \\
\hline $\begin{array}{c}\text { Month } \\
12\end{array}$ & $\begin{array}{l}\text { Animal } 1 \\
\text { Animal } 2 \\
\text { Animal } 3 \\
\end{array}$ & & & $\begin{array}{l}\text { Animal } 1 \\
\text { Animal } 3\end{array}$ & Animal 2 \\
\hline
\end{tabular}

Analogously, the same happens for months 8, 9 and 12; that is, each animal in the herd can have at least one of the remaining SPS-LA areas to be fed. Still in Table 1, we observe that in the southern area of pasture without trees, the only month of the year in which area does not present adequate feeding conditions for any animal of the herd is month 3 . However, for same month, the remaining areas may feed the herd. Regarding the silvopastoral area, we observe that it only shows availability of feed for animal 1 in months 5, 8, 9, 10 and 11. In summary, Table 1 reports, for each month of the year, the areas of SPS-LA where each animal can perform adequate feeding. Note that for each month of the year, each animal in the herd has exactly two SPS-LA areas for proper feeding.

Still in the first scenario, Table 2 contains the optimal solutions, or optimal routes, that each animal of the herd must make to gain fat during the period of one year. 
Table 2. Optimum occupation of the SPS-LA areas for three (3) animals

\begin{tabular}{c|c|c|c|c|c}
\hline & $\begin{array}{c}\text { Northern } \\
\text { confinement area }\end{array}$ & $\begin{array}{c}\text { Northern } \\
\text { area of pasture } \\
\text { without tree }\end{array}$ & $\begin{array}{c}\text { Silviopastoral } \\
\text { area }\end{array}$ & $\begin{array}{c}\text { Southern } \\
\text { area of pasture } \\
\text { without tree }\end{array}$ & $\begin{array}{c}\text { Southern } \\
\text { confinement } \\
\text { area }\end{array}$ \\
\hline Month 1 & Animal 1 & & & $\begin{array}{c}\text { Animal 2 } \\
\text { Animal 3 }\end{array}$ \\
\hline Month 2 & & & Animal 1 & $\begin{array}{c}\text { Animal 2 } \\
\text { Animal 3 }\end{array}$ \\
\hline Month 3 & & Animal 1 & & Animal 2 \\
Animal 3
\end{tabular}

For example, the optimal recommended route for animal 1 is that it be properly fed during month 1 in the northern area of no-tree pasture, month 2 in the southern area of no-tree pasture, in months 3 and 4, back in the northern area of pasture without trees, at month 5 in the silvipastoral area, at month 6 in the southern area of no-tree pasture, at month 7 in the northern pasture area without trees, months 8, 9 and 10 in the silvopastoral area, month 11 in the northern area of pasture without trees and, finally, in month 12 in the northern area of confinement.

In the same way, it is possible to know the optimal time of movement of animals 2 and 3 in SPS-LA. Regarding animal 2, we observe that it should remain the 12 months of the year in the southern SPS-LA confinement area. For animal 3, during the first three months of the year, it should remain in the southern area, remembering that during these months, animal 3 only has as viable areas for its feeding the northern and southern areas of confinement. The rest of the year, it should remain in the southern area of no-tree pasture (see Table 1). Also note in Table 2 that in each month of the year, each herd animal is optimally fed in one and only one SPS-LA area.

For the second scenario, Table 3 shows the results obtained for animals that may have had adequate feeding to gain fat in a certain area of SPS-LA $\left(x_{i j k}\right)$. In this second execution of the code implemented for a larger herd with five animals, three areas (northern and southern confinement areas and silvopastoral area) were obtained to feed the five animals in the same month. Moreover, for each month, there is at least one of these three areas with a possible capacity to feed all the herd considered. Theoretically, this means more options for a lower cost-benefit in the process of fattening. Note that in months 4,8 and 10, the only area of SPS-LA that is not adequate to feed any animal in the herd is the southern area of no-tree pasture. Note that for each month of the year, each animal in the herd has exactly three SPS-LA areas for proper feeding. 
Table 3. Availability of areas suitable for five (5) animals

\begin{tabular}{|c|c|c|c|c|c|}
\hline & $\begin{array}{c}\text { Northern } \\
\text { confinement } \\
\text { area }\end{array}$ & $\begin{array}{c}\text { Northern } \\
\text { area of pasture } \\
\text { without tree }\end{array}$ & $\begin{array}{c}\text { Silviopastoral } \\
\text { area }\end{array}$ & $\begin{array}{c}\text { Southern } \\
\text { area of pasture } \\
\text { without tree }\end{array}$ & $\begin{array}{c}\text { Southern } \\
\text { confinement area }\end{array}$ \\
\hline Month 1 & $\begin{array}{c}\text { Animal } 1 \\
\text { Animal } 2 \\
\text { Animal } 3 \\
\text { Animal } 4 \\
\text { Animal } 5\end{array}$ & $\begin{array}{l}\text { Animal } 1 \\
\text { Animal } 2\end{array}$ & $\begin{array}{l}\text { Animal } 3 \\
\text { Animal } 5\end{array}$ & Animal 4 & $\begin{array}{l}\text { Animal } 1 \\
\text { Animal } 2 \\
\text { Animal } 3 \\
\text { Animal } 4 \\
\text { Animal } 5 \\
\end{array}$ \\
\hline Month 2 & $\begin{array}{l}\text { Animal } 1 \\
\text { Animal } 2 \\
\text { Animal } 3 \\
\text { Animal } 4 \\
\text { Animal } 5 \\
\end{array}$ & $\begin{array}{l}\text { Animal } 1 \\
\text { Animal } 2\end{array}$ & $\begin{array}{l}\text { Animal } 3 \\
\text { Animal } 5\end{array}$ & Animal 4 & $\begin{array}{l}\text { Animal } 1 \\
\text { Animal } 2 \\
\text { Animal } 3 \\
\text { Animal } 4 \\
\text { Animal } 5 \\
\end{array}$ \\
\hline Month 3 & $\begin{array}{l}\text { Animal } 1 \\
\text { Animal } 2 \\
\text { Animal } 5\end{array}$ & $\begin{array}{l}\text { Animal } 1 \\
\text { Animal } 2 \\
\text { Animal } 4\end{array}$ & $\begin{array}{l}\text { Animal } 3 \\
\text { Animal } 5\end{array}$ & $\begin{array}{l}\text { Animal } 3 \\
\text { Animal } 4\end{array}$ & $\begin{array}{l}\text { Animal 1 } \\
\text { Animal } 2 \\
\text { Animal } 3 \\
\text { Animal } 4 \\
\text { Animal } 5 \\
\end{array}$ \\
\hline Month 4 & $\begin{array}{l}\text { Animal } 1 \\
\text { Animal } 2 \\
\text { Animal } 3 \\
\text { Animal } 4 \\
\text { Animal } 5 \\
\end{array}$ & $\begin{array}{l}\text { Animal } 1 \\
\text { Animal } 2 \\
\text { Animal } 4\end{array}$ & $\begin{array}{l}\text { Animal } 3 \\
\text { Animal } 5\end{array}$ & & $\begin{array}{l}\text { Animal } 1 \\
\text { Animal } 2 \\
\text { Animal } 3 \\
\text { Animal } 4 \\
\text { Animal } 5 \\
\end{array}$ \\
\hline Month 5 & $\begin{array}{l}\text { Animal } 1 \\
\text { Animal } 2 \\
\text { Animal } 5\end{array}$ & $\begin{array}{l}\text { Animal } 1 \\
\text { Animal } 2 \\
\text { Animal } 4\end{array}$ & $\begin{array}{l}\text { Animal } 3 \\
\text { Animal } 4 \\
\text { Animal } 5\end{array}$ & Animal 3 & $\begin{array}{l}\text { Animal } 1 \\
\text { Animal } 2 \\
\text { Animal } 3 \\
\text { Animal } 4 \\
\text { Animal } 5 \\
\end{array}$ \\
\hline Month 6 & $\begin{array}{l}\text { Animal } 1 \\
\text { Animal } 2 \\
\text { Animal } 3 \\
\text { Animal } 5\end{array}$ & $\begin{array}{l}\text { Animal } 1 \\
\text { Animal } 2 \\
\text { Animal } 4\end{array}$ & $\begin{array}{l}\text { Animal } 3 \\
\text { Animal } 5\end{array}$ & Animal 4 & $\begin{array}{l}\text { Animal } 1 \\
\text { Animal } 2 \\
\text { Animal } 3 \\
\text { Animal } 4 \\
\text { Animal } 5 \\
\end{array}$ \\
\hline Month 7 & $\begin{array}{l}\text { Animal } 1 \\
\text { Animal } 2 \\
\text { Animal } 3 \\
\text { Animal } 4 \\
\text { Animal } 5 \\
\end{array}$ & $\begin{array}{l}\text { Animal } 1 \\
\text { Animal } 2\end{array}$ & $\begin{array}{l}\text { Animal } 3 \\
\text { Animal } 4 \\
\text { Animal } 5\end{array}$ & Animal 4 & $\begin{array}{l}\text { Animal } 1 \\
\text { Animal } 2 \\
\text { Animal } 3 \\
\text { Animal } 5\end{array}$ \\
\hline Month 8 & $\begin{array}{l}\text { Animal } 1 \\
\text { Animal } 2 \\
\text { Animal } 3 \\
\text { Animal } 4 \\
\text { Animal } 5 \\
\end{array}$ & $\begin{array}{l}\text { Animal } 1 \\
\text { Animal } 2 \\
\text { Animal } 4\end{array}$ & $\begin{array}{l}\text { Animal } 3 \\
\text { Animal } 4 \\
\text { Animal } 5\end{array}$ & & $\begin{array}{l}\text { Animal } 1 \\
\text { Animal } 2 \\
\text { Animal } 3 \\
\text { Animal } 5\end{array}$ \\
\hline Month 9 & $\begin{array}{l}\text { Animal } 1 \\
\text { Animal } 2 \\
\text { Animal } 3 \\
\text { Animal } 4 \\
\text { Animal } 5 \\
\end{array}$ & $\begin{array}{l}\text { Animal } 1 \\
\text { Animal } 2 \\
\text { Animal } 4\end{array}$ & $\begin{array}{l}\text { Animal } 3 \\
\text { Animal } 4 \\
\text { Animal } 5\end{array}$ & Animal 3 & $\begin{array}{l}\text { Animal } 1 \\
\text { Animal } 2 \\
\text { Animal } 5\end{array}$ \\
\hline Month 10 & $\begin{array}{l}\text { Animal } 1 \\
\text { Animal } 2 \\
\text { Animal } 3\end{array}$ & $\begin{array}{l}\text { Animal } 1 \\
\text { Animal } 2 \\
\text { Animal } 4\end{array}$ & $\begin{array}{l}\text { Animal } 3 \\
\text { Animal } 4 \\
\text { Animal } 5\end{array}$ & & $\begin{array}{l}\text { Animal } 1 \\
\text { Animal } 2 \\
\text { Animal } 3 \\
\text { Animal } 4 \\
\text { Animal } 5\end{array}$ \\
\hline Month 11 & $\begin{array}{l}\text { Animal } 3 \\
\text { Animal } 4 \\
\text { Animal } 5\end{array}$ & $\begin{array}{l}\text { Animal } 1 \\
\text { Animal } 2\end{array}$ & $\begin{array}{l}\text { Animal } 1 \\
\text { Animal } 2 \\
\text { Animal } 3 \\
\text { Animal } 5\end{array}$ & $\begin{array}{l}\text { Animal } 3 \\
\text { Animal } 4\end{array}$ & $\begin{array}{l}\text { Animal } 1 \\
\text { Animal } 2 \\
\text { Animal } 4 \\
\text { Animal } 5\end{array}$ \\
\hline Month 12 & $\begin{array}{l}\text { Animal } 4 \\
\text { Animal } 5\end{array}$ & $\begin{array}{l}\text { Animal } 1 \\
\text { Animal } 2 \\
\text { Animal } 3\end{array}$ & $\begin{array}{l}\text { Animal } 1 \\
\text { Animal } 2 \\
\text { Animal } 3 \\
\text { Animal } 4 \\
\text { Animal } 5 \\
\end{array}$ & $\begin{array}{l}\text { Animal } 1 \\
\text { Animal } 2 \\
\text { Animal } 5\end{array}$ & $\begin{array}{l}\text { Animal } 3 \\
\text { Animal } 4\end{array}$ \\
\hline
\end{tabular}

Still in the second scenario, as in Table 2, Table 4 contains the optimal solutions, or optimal 
routes that each animal of the herd must make to gain fat during the period of one year. Note that for each month of the year, each herd animal is fed adequately in one and only one SPS-LA region, and although the northern and southern confinement areas are the most viable areas to feed all herds considered (see Table 3), they are not the most used spaces in the optimal solution. This is due to the high cost of using these areas. The animal is destined to the confinement area (north or south) in only two cases: when the animal is underweight and when it is not possible to send it to another area and meet the restrictions imposed. Note also that animals 2 and 5 can be optimally and properly fed (during the year) in the northern pasture area without trees and in the silvopastoral area. Also note in Table 2 that in each month of the year, each herd animal must be optimally fed in one and only one SPS-LA area.

Table 4. Optimum occupation of the SPS-LA areas for five (5) animals

\begin{tabular}{|c|c|c|c|c|c|}
\hline & $\begin{array}{c}\text { Northern } \\
\text { confinement } \\
\text { area }\end{array}$ & $\begin{array}{c}\text { Northern } \\
\text { area of pasture } \\
\text { without tree }\end{array}$ & $\begin{array}{c}\text { Silviopastoral } \\
\text { area }\end{array}$ & $\begin{array}{c}\text { Southern } \\
\text { area of pasture } \\
\text { without tree }\end{array}$ & $\begin{array}{c}\text { Southern } \\
\text { confinement } \\
\text { area }\end{array}$ \\
\hline Month 1 & Animal 1 & Animal 2 & Animal 5 & Animal 3 & Animal 4 \\
\hline Month 2 & Animal 1 & Animal 2 & Animal 5 & Animal 4 & Animal 3 \\
\hline Month 3 & & $\begin{array}{l}\text { Animal } 1 \\
\text { Animal } 2 \\
\text { Animal } 4 \\
\end{array}$ & Animal 5 & Animal 3 & \\
\hline Month 4 & & $\begin{array}{l}\text { Animal } 1 \\
\text { Animal } 2 \\
\text { Animal } 4\end{array}$ & $\begin{array}{l}\text { Animal } 3 \\
\text { Animal } 5\end{array}$ & & \\
\hline Month 5 & Animal 1 & Animal 2 & $\begin{array}{l}\text { Animal } 3 \\
\text { Animal } 5 \\
\text { Animal } 4\end{array}$ & & \\
\hline Month 6 & Animal 1 & $\begin{array}{l}\text { Animal } 2 \\
\text { Animal } 4\end{array}$ & $\begin{array}{l}\text { Animal } 3 \\
\text { Animal } 5\end{array}$ & & \\
\hline Month 7 & Animal 1 & Animal 2 & $\begin{array}{l}\text { Animal } 3 \\
\text { Animal } 5\end{array}$ & Animal 4 & \\
\hline Month 8 & Animal 1 & $\begin{array}{l}\text { Animal } 2 \\
\text { Animal } 4\end{array}$ & $\begin{array}{l}\text { Animal } 3 \\
\text { Animal } 5\end{array}$ & & \\
\hline Month 9 & & $\begin{array}{l}\text { Animal } 1 \\
\text { Animal } 2\end{array}$ & $\begin{array}{l}\text { Animal } 3 \\
\text { Animal } 5 \\
\text { Animal } 4 \\
\end{array}$ & & \\
\hline $\begin{array}{l}\text { Month } \\
10\end{array}$ & & $\begin{array}{l}\text { Animal } 1 \\
\text { Animal } 2 \\
\text { Animal } 4\end{array}$ & $\begin{array}{l}\text { Animal } 3 \\
\text { Animal } 5\end{array}$ & & \\
\hline $\begin{array}{l}\text { Month } \\
11\end{array}$ & Animal 4 & $\begin{array}{l}\text { Animal } 1 \\
\text { Animal } 2\end{array}$ & $\begin{array}{l}\text { Animal } 3 \\
\text { Animal } 5\end{array}$ & & \\
\hline $\begin{array}{l}\text { Month } \\
12\end{array}$ & Animal 4 & Animal 2 & $\begin{array}{l}\text { Animal } 1 \\
\text { Animal } 3 \\
\text { Animal } 5\end{array}$ & & \\
\hline
\end{tabular}

In the whole linear programming model presented previously, the objective was to maximize $\sum_{i=1}^{n} \sum_{j=1}^{5} \sum_{k=1}^{12} g_{i j k} y_{i j k}-\sum_{i=1}^{n} \sum_{j=1}^{5} \sum_{k=1}^{12} c_{i j k} x_{i j k}$, where $g_{i j k}$ represents the economic gain (R\$) by increasing the live weight of the animal $i$, when you are in the area $j$, in the month $k$, and $c_{i j k}(\mathrm{R} \$)$ represents the cost of keeping the animal $i$, when you are in the area $j$, in the 
month $k$. For randomly generating parameters $g_{i j k}$ and $c_{i j k}$ using the MATLAB computational platform, we obtained an optimal value of $\mathrm{R} \$ 6,615.25$ in the first scenario and of $\mathrm{R} \$ 45,987.33$ in the second scenario. This difference can be explained mainly by the lower use of confinement areas for fattening, which are the costliest areas for gain of live weight of each animal (see Table 1, Table 2).

\section{Conclusions}

In the first place the work presented a conceptual physical platform of the agroforestry center "La Aguada", in the National University of Rio Cuarto (Córdoba-Argentina), denominated SPS-LA, as well as a set of rules related to the allowed animal traffic between the different areas of the system, always seeking an increase in the live weight of each animal in the herd, and considering the monthly availability that each SPS-LA area has to feed or receive each animal. Then, we defined the variables associated to the animal permanence in each area and month of the year, the variables related to the availability that each area of the system has to receive or feed animals of the herd considered, and the system of linear inequalities that represents the viability of the rules imposed on moving animals in SPS-LA. Moreover, through parameters that quantify the economic gain by increasing the live weight of each animal and the cost of availability of each area of the SPS-LA, the so-called objective function of the integer linear program associated to both the pasture control (with and without trees) and optimal movement in SPS-LA (together with its model constraints) was generated and solved using the INTLINPROG solver in MATLAB software, thus finding an optimal solution. After the computational implementation, we verified that the program meets all constraints imposed, maximizes the live weight gain of each animal and optimizes pasture area use, showing to be a consistent, balanced and recommended program for the economic controlling of silvopastoral systems in general.

\section{References}

Bernardino, F. S., Garcia, R., \& Sistemas, S. (2009). Pesquisa Florestal Brasileira, Colombo, $60,77-87$.

Franke, I. L., \& Furtado, S. C. (2001). Sistemas silvipastoris: fundamentos e aplicabilidade. Rio Branco, AC: Embrapa Acre, 51 p. il color (Embrapa Acre. Documentos, 74).

Galdino de Oliveira, D., Delgado, A. R. S., Drumond Ventura, S., Dib Cruz, M., \& Parga Rodrigues, P. C. (2019). Binary programming for the simulation of crop rotation and animal transit in an integrated crop-livestock system. Revista Ciência Agronômica, 50(2), 123-130. https://doi.org/10.5935/1806-6690.20190015

García, B., L., \& Ong, C. K. (2004). Ecological interactions, management lessons and 12 design tools in tropical agroforestry systems. Agroforestry Systems 61, 221-236. https://doi.org/10.1007/978-94-017-2424-1_16

Macedo, M. C. M., Kichel, A. N., \& Zimmer, A. H. (2000). Degradação e alternativas de recuperação e renovação de pastagens. Campo Grande: EMBRAPA-CNPGC, 4. (Comunicado 
Técnico, 62).

Nemhauser, G. L., \& Wolsey, L. A. (1999). Integer and combinatorial optimization. New York: Wiley-Interscience, 2-20.

Plevich, J. O., Gyenge, J., Delgado, A. R. S., Tarico, J. C., Fiandino, S., \& Utello, M. J. (2019). Production of Fodder in a Treeless System and in Silvopastoral System in Central Argentina. Revista Floresta e Ambiente; 26(1), 1-12. https://doi.org/10.1590/2179-8087.051716

Saibro, J. C., Castilhos, Z. N. S., Silva, J. L. S. et al. (2004). Gestão de sistemas silvipastoris no Rio Grande do Sul: desempenho animal. In: SIMPÓSIO LATINO-AMERICANO SOBRE MANEJO FLORESTAL, 3, Santa Maria. Anais... Santa Maria, RS: UFSM,.

Santos, L. D. T. (2010). Integração lavoura-pecuária-floresta: alternativa para produção sustentável nos trópicos. Montes Claros: Instituto de Ciências Agrárias da Universidade Federal de Minas Gerais.

Silva, J. L. S. (1998). Produtividade de componentes de um sistema silvipastoril constituído por Eucaliptus saligna e pastagens cultivada e nativa no Rio Grande do Sul. 178p. Tese (Doutorado em Zootecnia) - Universidade Federal de Viçosa, Viçosa.

\section{Copyright Disclaimer}

Copyright for this article is retained by the author(s), with first publication rights granted to the journal.

This is an open-access article distributed under the terms and conditions of the Creative Commons Attribution license (http://creativecommons.org/licenses/by/4.0/). 